\title{
FACTORS OF COMPANY VALUE: A STUDY BASED ON INTELLECTUAL CAPITAL, COMPANY GROWTH, AND COMPANY PERFORMANCE
}

\author{
Fahmi Achmad Faisal, Suwandi, Nyimas Wardatul Afiqoh \\ Universitas Muhammadiyah Gresik
}

\begin{abstract}
This study aims to examine the effect of intellectual capital, growth, and company performance. This research uses a quantitative approach and the sample used is 32 manufacturing companies listed on the Indonesia Stock Exchange (IDX) for the 2013-2017 periods which were obtained through a purposive sampling method. The analytical technique used is multiple linear regressions with the help of SPPS 2.2 for Windows. The results of the study show that the variable intellectual capital and company performance have a significant positive effect on the value of the company in manufacturing companies, this indicates that these two variables can be made by investors as a measure of investment in the company. Instead, the growth variable of the company shows a non-significant negative effect on the value of the company, it can be interpreted that the growth of the company is not a consideration of investors to invest in the company. The percentage of the influence of independent variables is Intellectual Capital, Company Growth and Performance.
\end{abstract}

Keywords: company performance, intellectual capital, company value, company growth

\section{INTRODUCTION}

The current rapid development of technology and business sill create competitiveness between companies; thus, each company is responsible to increase their company value to achieve their company goals. According to Brigham \& Houston (2010), the main goal of a company is to maximize the company's value, which is used to measure the success of the company because increasing company value means increasing the prosperity of the company's

\footnotetext{
*Corresponding Author.

e-mail: fahmiachmad141@gmail.com
} 
owner or the shareholders. Company value is measured by several aspects, one of them is the market price of the company's shares as company shares reflects the investor's evaluation of the total equity held by the company. One of the alternatives used to assess company value is using Tobin's Q. The ratio is developed by Profesor James Tobin (1967). The ratio is a valuable concept because it indicates the estimate value of the current financial market about the return from each dollar of incremental investment.

An increase of company value can happen because of several factors, such as liquidity, funding decisions, etc., so many investors are looking for alternatives as a consideration to invest in a company's capital. The alternative that can be taken is intellectual capital. This can happen because many investors have not seen intellectual capital as a measuring tool for investment in Indonesia. According to Stewart, Intellectual Capital is the intellectual material of knowledge, information, intellectual property rights, experience that can be used to create wealth. (Ulum, 2009). A research by Kuryanto \& Syafrudin (2012) explains that intellectual capital in Indonesia has not been widely known and most companies are still conventional based oriented in developing their business, so that the products created tend to not use advanced technology. Currently, company value measurement is no longer based on tangible assets. The measurement has been replaced based on intangible assets, not in physical form but is very valuable, such as company intellectuals, brands, or resources (Petty \& Guthrie, 2000).

According to previous studies, intellectual capital consists of three main elements, namely human capital or organizational capital, and relational capital or customer capital (Sawarjuwono, 2003). This is also the reason why Sirojudin \& Nazaruddin (2014) examined the effect of intellectual capital and its disclosures on company value and performance, where the study found that intellectual capital affects company value. Quantitative intellectual capital research is calculated by "Value Added Intellectual Coefficient" (VAIC ${ }^{\mathrm{TM}}$ ) that was introduced by Pulic (1998), and was made with the aim of providing information about how can company value creation can be efficient in terms of tangible and intangible assets. The VAIC ${ }^{\mathrm{TM}}$ is divided into three elements, which are Value Added Human Capital (VAHC), Value Added Capital Employed (VACE), and Value-Added Structural Capital (VASC). 
Apart from intellectual capital, company growth can also act as a measurement of company value. Company growth is the result of changes in cash flow originating from operations due to an increase or decrease in business volume (Helfert, 1997). Company growth is measured from the growth of total assets which will be describe by the future company growth (Taswan, 2003). In another study, company growth reflects the growth of company assets that affect company's financial performance, which is believed that the percentage of change in total assets is a good indicator in measuring company growth (Izza, 2013). This is consistent with a research by Kusumajaya (2011) where the researcher found that company growth towards company value, where the results of the research proves that the effect of company growth has a positive and significant effect towards firm value. This may indicate that company's growth receives a positive response from the investors because the company can raise stock prices.

Company value can be improved by the company's performance in generating profits and share value. Company performance itself describes the result achieved by a company within a certain period with the available physical capital (Susanti, 2010). Measuring company performance can be done via ROE (Return of Equity). ROE is used to measure how much profit the company can generate for every dollar of shareholder equity. If the ROE is higher than the cost of capital used, it indicates that the company uses its own capital efficiently, thus the profits earned will increase from the previous year (Angkoso, 2006).

Based on the explanation above, this study aims to find empirical evidence about the effect of intellectual capital, growth, and company performance towards company value. This study is a development of previous research conducted by Kusumajaya (2011) and Sukiati et al. (2015). The hypothesis of this study is based on the effect of intellectual capital, company growth and company performance towards firm value, which is as follow:

H1: Intellectual Capital Affects Company Value

H2: Company Growth Affects Company Value

H3: Company Performance Affects Company Value 


\section{METHOD}

\section{Population and Sample}

This study is conducted in Investment Gallery of the Indonesia Stock Exchange, Universitas Muhammadiyah Gresik, namely manufacturing companies listed on IDX based on the annual financial report data from 2013-2017 which were taken directly from www.idx.co.id. The research sample criteria are:

1. The manufacturing company has gone public within the 2013-2017 periods.

2. The company publishes annual report in the company's website and the IDX website in 2013-2017 and is stated in Rupiah (IDR).

3. The manufacturing companies did not show negative profit and equity during the 2013-2017 periods.

4. The manufacturing companies show positive asset change values during the 2013-2017 periods.

\section{Operational Definition of Variables}

The definition of the concept of variables, symbols, and formulas (measurements) for each research variable and the operationalization of the variables can be seen in the table below, which presents the research variables, indicators, measurement method and calculation, and the scale used in this study.

Table 1 Operational Definition of Variables

\begin{tabular}{|c|c|c|c|}
\hline Variable & Definition & Measurement/Calculation & Scale \\
\hline $\begin{array}{l}\text { Tobins'Q } \\
\text { (Company } \\
\text { Value= Y) }\end{array}$ & $\begin{array}{l}\text { Smithers dan } \\
\text { Wright (2007:37), } \\
\text { Tobin's Q the } \\
\text { company's market } \\
\text { stock value added } \\
\text { by debt divided to } \\
\text { the company's total } \\
\text { assets }\end{array}$ & Company value $=\frac{\text { Total Debt }+(\text { stock value })}{\text { Total asset }}$ & Ratio \\
\hline $\begin{array}{l}\text { VAIC }^{\mathrm{TM}} \\
\text { (Intellectual } \\
\text { Capital (X1)) }\end{array}$ & $\begin{array}{l}\text { Measuring the } \\
\text { performance of the } \\
\text { company's } \\
\text { intellectual capital } \\
\text { in creating value } \\
\text { added for the } \\
\text { company. } \\
\text { Pulic (1998) }\end{array}$ & $\begin{array}{l}\text { 1. VA }=\text { OUT }- \text { IN } \\
\text { OUT: Total sales and other income. } \\
\text { IN : Load and Expenses (other than employee } \\
\text { expenses) } \\
\text { 2. VACE }=\frac{\mathrm{VA}}{\mathrm{CE}} \\
\text { Value Added (VA): Difference between output } \\
\text { and input. } \\
\text { Capital Employed (CE): Available funds (equity) }\end{array}$ & Ratio \\
\hline
\end{tabular}


Fahmi Achmad Faisal, Suwandi, Nyimas Wardatul Afiqoh / Factors of Company Value: A Study Based on Intellectual Capital, Company Growth, and Company Performance

Company

Growth (X2)

ROE

(Company

Performance

(X3))
The difference between the total assets owned by the company in the current period with the previous period to the total assets of the previous period. Kusumajaya (2011) Indicates the strength of profit of the shareholder's book value investment and is used $t$ compare two or more companies in an industry on a continuous basis (Van Horne, 1989, p. 129)
3. $\mathrm{VAHC}=\frac{\mathrm{VA}}{\mathrm{HC}}$

Value Added (VA): The difference between output and input Human Capital (HC):

Employee Expenses

4. $\mathrm{VASC}=\frac{\mathrm{SC}}{\mathrm{VA}}$

Structural Capital (SC): The difference between value added (VA) and human capital (HC) . Value Added (VA): The difference between output and input Human capital (HC): Employee expenses

5. $\mathrm{VAIC}^{\mathrm{TM}}=\mathrm{VACE}+\mathrm{VAHC}+\mathrm{VASC}$

Ratio

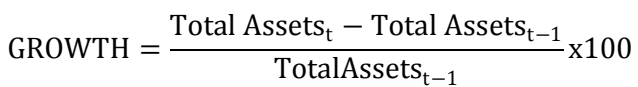

Ratio

$$
\text { ROE }=\frac{\text { Net Profit }}{\text { Equity }}
$$

\section{Method of Analysis}

The study conducted several data analysis testing techniques through descriptive statistical analysis, normality test, autocorrelation test, heteroscedasticity test, and multicollinearity test. In addition, the data are analysed by testing the hypothesis through a series of indicators, namely Multiple Linear Regression Analysis, Simultaneous Significance Test (F-test), Partial Significance Test (t-test), and the Determination Coefficient Test $\left(\mathrm{R}^{2}\right)$.

\section{RESULTS}

The data examined in this study includes secondary data in the form of annual report. The research object are all manufacturing companies listed on the Indonesia Stock Exchange from 2013-2017, which are classified as several 
Journal of Accounting, Entrepreneurship, and Financial Technology

Volume 02, Number 02, April 2021

sectors. Among others: (1) basic industrial sector and chemicals, (2) miscellaneous industry sector, and (3) industrial consumer goods sector. The sample group of this study includes the following:

Table 2 Sampling Process

\begin{tabular}{clcc}
\hline No. Criteria & Amount \\
\hline 1 & $\begin{array}{l}\text { Manufacturing company listed on the IDX within the 2013-2017 } \\
\text { period }\end{array}$ & 161 \\
2 & $\begin{array}{l}\text { Manufacturing companies that have gone public on the IDX } \\
\text { consecutively for the 2013-2017 period }\end{array}$ & $(31)$ \\
2 & $\begin{array}{l}\text { Manufacturing companies that did not use Rupiah in presenting their } \\
\text { financial statements }\end{array}$ & $(29)$ \\
3 & $\begin{array}{l}\text { Manufacturing companies that did not show positive profit and } \\
\text { equity during the 2013-2017 period. }\end{array}$ & (41) \\
4 & $\begin{array}{l}\text { Manufacturing companies that did not show positive asset value } \\
\text { change in 2013-2017 }\end{array}$ & (28) \\
The Total of Research Samples (Manufacturing Companies)
\end{tabular}

Source: www.idx.com (2019)

From the table above, it shows that total sample acquired for this study are 32 companies. The names of the companies that are included in this study are presented in Table 3 below.

Table 3 Sampling Process

\begin{tabular}{clcl}
\hline No. & Company & No. & Company \\
\hline 1 & Semen Baturaja Tbk & 19 & Mayora Indah Tbk \\
2 & Semen Indonesia (Persero) Tbk & 20 & Nippon Indosari Corpindo Tbk \\
3 & Asahimas Flat Glass Tbk & 21 & Sekar Bumi Tbk \\
4 & Arwana Citramulia Tbk & 22 & Sekar Laut Tbk \\
5 & Surya Toto Indonesia Tbk & 23 & Siantar Top Tbk \\
6 & Steel Pipe Industry of Indonesia Tbk & 24 & Ultra Jaya Milk Industry and Trading Com \\
7 & Duta Pertiwi Nusantara Tbk & 25 & Kimia Farma Tbk \\
8 & Champion Pacific Indonesia Tbk & 26 & H.M. Sampoerna Tbk \\
9 & Japfa Comfeed Indonesia Tbk & 27 & Darya Varia Laboratoria Tbk \\
10 & Alkindo Naratama Tbk & 28 & Tempo Scan Pacific Tbk \\
11 & Astra International Tbk & 29 & Kalbe Farma Tbk \\
12 & Nipress Tbk & 30 & Akasha Wira International Tbk \\
13 & Selamat Sempurna Tbk & 31 & Mandom Indonesia Tbk \\
14 & Ricky Putra Globalindo Tbk & 32 & Unilever Indonesia Tbk \\
15 & Sepatu Bata Tbk & & \\
16 & KMI Wire \& Cable Tbk & & \\
17 & Delta Djakarta Tbk & & \\
18 & Indofood CBP Sukses Makmur Tbk & & \\
\hline
\end{tabular}

Sumber: www.idx.com (2019) 
Fahmi Achmad Faisal, Suwandi, Nyimas Wardatul Afiqoh / Factors of Company Value: A Study Based on Intellectual Capital, Company Growth, and Company Performance

\section{Descriptive Statistical Analysis}

The data analysis used in this study is multiple linear regression analysis using the SPSS program. Based on the list of company and data on Company value (Tobins'Q), Intellectual Capital (VAIC ${ }^{\mathrm{TM}}$ ), Company Growth (GROWTH), and Company Performance (ROE) processed through the SPSS program, the results of descriptive statistic are shown as follow:

Table 4 Descriptive Statistic

\begin{tabular}{lccccc}
\hline & N & Minimum & Maximum & Mean & $\begin{array}{c}\text { Std. } \\
\text { Deviation }\end{array}$ \\
\cline { 2 - 6 } Company Value & 160 & .3000 & 23.2860 & 3.012694 & 3.5944067 \\
Intellectual Capital & 160 & 1.2880 & 23.8290 & 3.879525 & 2.8948437 \\
Company Growth & 160 & .0010 & 1.2620 & .162600 & .1550932 \\
Company & 160 & .0030 & 1.3590 & .204031 & .2284818 \\
Performance & 160 & & & & \\
Valid N (listwise) & 160 & & & \\
\hline
\end{tabular}

According to Table 4, it is seen that the total data in this study includes (32 samples $\mathrm{x} 5$ years) $=160$ data. However, the first test identified 7 data as outlier data. Outlier data is data that has a range value far above or below the average value of other data. Thus, the final samples that can be processed is 153 data samples.

Table 5 Descriptive Statistics After the Outlier

\begin{tabular}{lccccc}
\hline & $\mathbf{N}$ & Minimum & Maximum & Mean & Std. Deviation \\
\cline { 2 - 6 } Company Value & 153 &, 3000 & 18,6400 & 2,643667 & 2,9859853 \\
Intellectual Capital & 153 & 1,2880 & 23,8290 & 3,814967 & 2,9190225 \\
Company Growth & 153 &, 0010 & 1,2620 &, 162229 &, 1567358 \\
Company Performance & 153 &, 0030 & 1,3590 &, 195294 &, 2123606 \\
Valid N (listwise) & 153 & & & & \\
\hline
\end{tabular}

Tabel 5 above shows that the average value of each variable are positive. In Table 5 , it is seen that company value range between 0,3000 and 18,6400 with a mean value of 2,643667 and standard deviation of 2,9859853. The company with the lowest value is PT KMI Wire \& Cable Tbk in 2016 valuing 0,3000, while the highest company value was achieved by PT Unilever Indonesia Tbk in 2015 with the value of 18,6400 . 
Intellectual capital range between 1,2880 and 23,8290 with a mean value of 3,8149 and standard deviation of 2,9190. The company with the lowest intellectual capital is PT Steel Pipe Industry of Indonesia Tbk in 2017 valuing 1,2880, while the company with the highest intellectual capital is PT Delta Djakarta Tbk in 2014 with the value of 23,8290.

Company growth range between 0,0010 and 1,2620 with a mean value of 0,1622 and standard deviation of 0,1567. The company with the lowest company growth is PT Steel Pipe Industry of Indonesia Tbk showing a growth of 0,0010 pada tahun 2015. While the highest company growth is achieved by PT Semen Baturaja Tbk in 2013 amounting 1,2620.

Company performance range between 0,0030 and 1,3590 with a mean value of 0,1952 and standard deviation of 0,2123 . The company with the lowest company performance is PT Steel Pipe Industry of Indonesia Tbk in 2017 amounting 0,0030, while the highest company performance is achieved by PT Unilever Indonesia Tbk in 2016 with company performance valuing on 1,3590.

\section{Classic Assumption Test}

The data analysis used in this study is multiple linear regression analysis using the SPSS program. Prior to performing the regression testing, it is necessary to conduct a classical assumption test to find out whether there is any multicollinearity, heteroscedasticity, or autocorrelation in the data to be tested.

\section{Normality Test}

Table 6 Kolmogrov-Smirnov Test

\begin{tabular}{llr}
\hline & & $\begin{array}{c}\text { Unstandardized } \\
\text { Residual }\end{array}$ \\
\hline $\mathrm{N}$ & Mean & 153 \\
Normal & &, 0000000 \\
Parameters(a,b) & Std. Deviation & 1,16473512 \\
Most Extreme & Absolute &, 105 \\
Differences & &, 066 \\
& Positive &,- 105 \\
Kolmogorov-Smirnov Z & Negative & 1,296 \\
Asymp. Sig. (2-tailed) & &, 069 \\
\hline
\end{tabular}


According to the result of the normality test presented on Table 6 above, it can be stated that the data used in this research model is normally distributed. The indication of data normality can be seen from the value of Asymp. Sig (20-tailed) where it is bigger than 0,05 . The value of Asymp. Sig (20-tailed) from this testing is at 0,069 which is greater than 0,05 . Thus, the statement stated that the research data is normally distributed is in accordance with the appropriate criteria.

\section{Normal P-P Plot of Regression Standardized Residual}

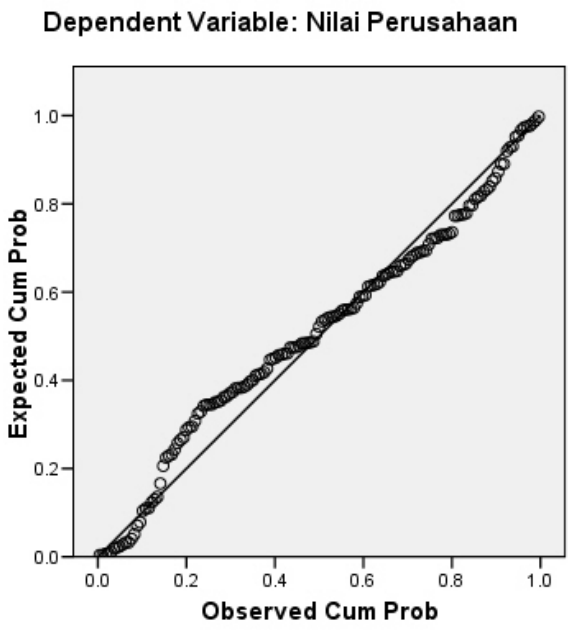

Figure 1 Normality Test

Figure 1 shows the result of normality test using the P-P Plot. From the result of the graphic test, it shows that the data spreads around the diagonal line and follows the direction of the diagonal line or the histogram line showing a normal distribution pattern. Thus, the regression model fulfils the normality assumptions.

Autocorrelation Test

Table 7 Autocorrelation Test

\begin{tabular}{rrrrrr}
\hline Model & R & R Square & Adjusted R Square & Std. Error of the Estimate & Durbin-Watson \\
\hline 1 &, $921(\mathrm{a})$ &, 848 &, 845 & 1,1764022 & 1,969 \\
\hline
\end{tabular}

a Predictors: (Constant), Company Performance, Company Growth, Intellectual Capital

b Dependent Variable: Company Value 
Journal of Accounting, Entrepreneurship, and Financial Technology

Volume 02, Number 02, April 2021

From Table 7, it is known that the value of DW is 1,969. According to the Durbin Watson criteria, the autocorrelation test is fulfilled if bila $\mathrm{dU} \leq \mathrm{d} \leq(4-\mathrm{dU})$. In this study the value of $\mathrm{dL}=1,6959$ and $\mathrm{dU}=1,7758$. So, $7758 \leq 1.969 \leq 2.2242$, meaning that the result of the autocorrelation test is $\mathrm{dU} \leq \mathrm{d} \leq(4-\mathrm{dU})$, thus it is said that no autocorrelation found in the data.

\section{Heteroskedasticity Test}

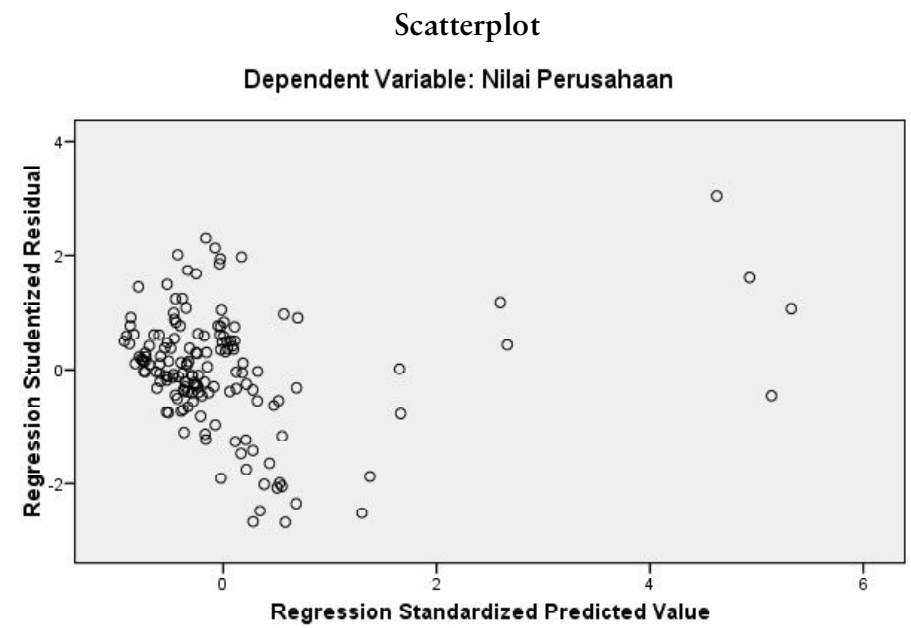

Figure 2 Heteroscedasticity Test

From Figure 2 above, it shows that the dots spread with an unclear pattern above ad below the number 0 in the $\mathrm{Y}$ axis. Thus, it can be inferred that the regression model does not show any heteroscedasticity issues.

\section{Multicollinearity Test}

Table 8 Multicollinearity Test

\begin{tabular}{|c|c|c|c|c|c|c|c|c|}
\hline \multicolumn{9}{|c|}{ Coefficients $^{a}$} \\
\hline \multirow{2}{*}{\multicolumn{2}{|c|}{ Model }} & \multicolumn{2}{|c|}{$\begin{array}{l}\text { Unstandardized } \\
\text { Coefficients }\end{array}$} & \multirow{2}{*}{$\begin{array}{c}\begin{array}{c}\text { Standardized } \\
\text { Coefficients }\end{array} \\
\text { Beta } \\
\end{array}$} & \multirow[t]{2}{*}{$\mathrm{t}$} & \multirow[t]{2}{*}{ Sig. } & \multicolumn{2}{|c|}{$\begin{array}{l}\text { Collinearity } \\
\text { Statistics }\end{array}$} \\
\hline & & B & Std. Error & & & & Tolerance & VIF \\
\hline 1 & (Constant) &,- 074 & ,191 & &,- 390 & 697 & & \\
\hline & Intellectual Capital & ,118 & 038 & 115 & 3,104 & ,002 & ,741 & 1,349 \\
\hline & Company Growth &,- 478 & ,612 &,- 025 &,- 781 & ,436 & 990 & 1,010 \\
\hline & $\begin{array}{l}\text { Company } \\
\text { Performance }\end{array}$ & 12,012 & ,524 & 854 & 22,915 & , 000 & ,735 & 1,361 \\
\hline
\end{tabular}


From the results of the data processing, it is obtained a tolerance value of higher than 0.10 and a VIF of lessen than 10 . It can be concluded that the variables used do not have multicollinearity issues.

\section{Multiple Linear Regression Test}

Multiple linear regression analysis is used to analyse the effect of the independent variable $(\mathrm{X})$ to the dependent variable $(\mathrm{Y})$. This research was conducted through SPSS version 22. The results of the multiple linear regression test are as follow:

Table 9 Multiple Linear Regression Test

\begin{tabular}{|c|c|c|c|c|c|c|c|c|}
\hline \multicolumn{9}{|c|}{ Coefficients $^{a}$} \\
\hline & \multirow[t]{2}{*}{ Model } & \multicolumn{2}{|c|}{$\begin{array}{c}\text { Unstandardized } \\
\text { Coefficients } \\
\end{array}$} & \multirow{2}{*}{$\begin{array}{c}\text { Standardized } \\
\text { Coefficients } \\
\text { Beta }\end{array}$} & \multirow[t]{2}{*}{$\mathrm{t}$} & \multirow[t]{2}{*}{ Sig. } & \multicolumn{2}{|c|}{$\begin{array}{c}\text { Collinearity } \\
\text { Statistics }\end{array}$} \\
\hline & & B & Std. Error & & & & Tolerance & VIF \\
\hline 1 & (Constant) &,- 074 & ,191 & &,- 390 & 697 & & \\
\hline & Intelectual Capital & ,118 & ,038 & ,115 & 3,104 & ,002 & ,741 & 1,349 \\
\hline & Company Growth &,- 478 & 612 &,- 025 &,- 781 & ,436 & ,990 & 1,010 \\
\hline & Company & 12,012 & ,524 & ,854 & 22,915 & , 000 & ,735 & 1,361 \\
\hline & Performance & & & & & & & \\
\hline
\end{tabular}

Table 9 shows the result of the multiple linear regression test that has been arranged into a regression equation below:

$\mathrm{Y}=\mathrm{a}+\mathrm{b} 1 \mathrm{X} 1+\mathrm{b} 2 \mathrm{X} 2+\mathrm{b} 3 \mathrm{X} 3+\mathrm{e}$ thus:
Company Value $\left(\right.$ Tobins'Q) $=-0,074+0,118$ VAIC $^{\text {TM }}-0.478$ GROWTH + $12,012 \mathrm{ROE}+\mathrm{e}$

The result of the multiple linear regression equation above shows that the constant value is $-0,074$. This indicates that the Tobins' $Q$ has a value of $-0,074$ and is not influenced by independent variables (Intellectual Capital, Company Growth, and Company Performance). The regression equation above has the following meaning:

a) The Intellectual Capital Variable (VAIC ${ }^{\mathrm{TM}}$ ) shows a positive and significant influence on Company Value (Tobins'Q) with a coefficient value of 0,118. This means that every time 1 unit of intellectual capital increases, company value will increase by 0,118 assuming the other variables are constant. 
b) The Company Growth Variable (GROWTH) shows a negative and insignificant effect on company value (Tobins'Q) with a coefficient value of -0.478 . The negative sign on the coefficient indicates a decrease from 1 unit of company growth will result in a decrease in company value by 0,478 assuming the other variables are constant.

c) Company Performance (ROE) shows a positive and significant effect on company value (Tobins' $Q$ ) with a coefficient value of 12,021 . The positive coefficient value means that every 1 unit of company performance will result in an increase of company value by 12,021 assuming the other variables are constant.

\section{F-test (Simultaneous)}

Table 10 F-test (Simultaneous)

\begin{tabular}{llrrrrr}
\hline \multirow{2}{*}{ Model } & \multicolumn{1}{c}{$\begin{array}{c}\text { Sum of } \\
\text { Squares }\end{array}$} & df & Mean Square & F & \multirow{2}{*}{ Sig. } \\
\hline 1 & Regression & 1149,044 & 3 & 383,015 & 276,760 &, $000(\mathrm{a})$ \\
& Residual & 206,204 & 149 & 1,384 & & \\
& Total & 1355,248 & 152 & & & \\
\hline
\end{tabular}

a Predictors: (Constant), Company Performance, Company Growth, Intellectual Capital

b Dependent Variable: Company Value

Table 10 shows the value of $\mathrm{F}$ count, which is 276,760 . While the $\mathrm{F}$ table is at the $5 \%$ significance level and $\mathrm{f} 1(\mathrm{~N} 1)=\mathrm{k}-1=4-1=3$, df2 $(\mathrm{N} 2)=153$ $4=149$. Thus, the f-table is 2,67 . This means that $\mathrm{F}$ count $>\mathrm{F}$ table $(276,760$ $>2.67$ ) with a significant level of 0.000 .

In this case, the variables of intellectual capital, company growth, and company performance simultaneously have a significant effect on company value.

\section{t-test (Partial)}

Table 11 t-test (Partial)

\begin{tabular}{|c|c|c|c|c|c|c|c|c|}
\hline \multicolumn{9}{|c|}{ Coefficients $^{\mathrm{a}}$} \\
\hline \multirow{2}{*}{\multicolumn{2}{|c|}{ Model }} & \multicolumn{2}{|c|}{$\begin{array}{l}\text { Unstandardized } \\
\text { Coefficients }\end{array}$} & \multirow{2}{*}{$\begin{array}{c}\begin{array}{c}\text { Standardized } \\
\text { Coefficients }\end{array} \\
\text { Beta }\end{array}$} & \multirow[t]{2}{*}{$\mathrm{t}$} & \multirow[t]{2}{*}{ Sig. } & \multicolumn{2}{|c|}{$\begin{array}{c}\text { Collinearity } \\
\text { Statistics }\end{array}$} \\
\hline & & B & Std. Error & & & & Tolerance & VIF \\
\hline \multirow[t]{4}{*}{1} & (Constant) &,- 074 & ,191 & &,- 390 & ,697 & & \\
\hline & Intellectual Capital & 118 & 038 & ,115 & 3,104 &, 002 & ,741 & 1,349 \\
\hline & Company Growth &,- 478 & ,612 &,- 025 &,- 781 & ,436 & 990 & 1,010 \\
\hline & Performance & 12,012 & ,524 & 854 & 22,915 &, 000 & ,735 & 1,361 \\
\hline
\end{tabular}


Fahmi Achmad Faisal, Suwandi, Nyimas Wardatul Afiqoh / Factors of Company Value: A Study Based on Intellectual Capital, Company Growth, and Company Performance

\section{The Effect of Intellectual Capital on Company Value}

The second hypothesis testing in this study is to test whether the Intellectual Capital (X1) affects Company Value. The result shows that the $t$ count is 3,104 while the $\mathrm{t}$ table with a significance level of $5 \%$ and $\mathrm{df}=\mathrm{n}-\mathrm{k}=153-4=149$ is 1,976013 ( $\mathrm{t}$ count $>\mathrm{t}$ table $=3,104>1,976013$ ) with a significance value of 0,002, which means 0,002 <0,05. Thus, H1 is accepted and H0 is rejected.

Thus, it can be concluded that the intellectual capital variable has a positive and significant effect towards company value. The following is a curve figure to test the expectation norm.

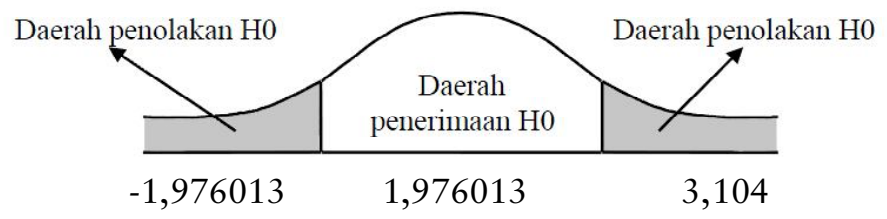

Figure 3 Intellectual Capital Curve Result

\section{The Effect of Company Growth on Company Value}

The second hypothesis in this study is to test whether the Company Growth (X2) affects Company Value. The result shows that the t count is $-0,0781$, while the $t$ table with a significance level of $5 \%$ and $\mathrm{df}=\mathrm{n}-\mathrm{k}=153-4=149$ is 1,976013 ( $\mathrm{t}$ count $>\mathrm{t}$ table $=3,104>1,976013$ ) with a significant value of 0.43 , which means that $0.436>0,05$. Thus, $\mathrm{H} 1$ is rejected and $\mathrm{H} 0$ is accepted.

Thus, it can be concluded that company stock growth has a negative and insignificant effect on company value. The graph below is a curve illustration to test the perception testing.

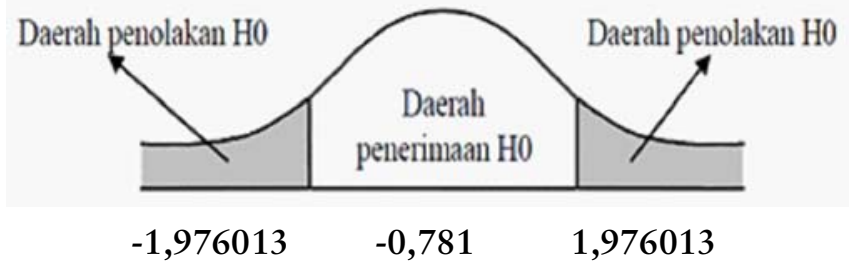

Figure 4 Company Growth Curve Result 


\section{The Effect of Company Performance on Company Value}

The second hypothesis in this study is to test whether the Company Growth (X2) affects Company Value. The result shows that the $t$ count is 22,195 , while the $\mathrm{t}$ table with a significance level of $5 \%$ and $\mathrm{df}=\mathrm{n}-\mathrm{k}=153-4=149$ is 1,976013 ( $\mathrm{t}$ count $>\mathrm{t}$ table $=322,195>1,976013$ ) with a significant value of 0.000 , which means that $0.000<0,05$. Thus, $\mathrm{H} 1$ is accepted and $\mathrm{H} 0$ is rejected.

Thus, it can be concluded that company variable has a positive and significant effect on company value. The graph below is a curve illustration to test the perception testing.

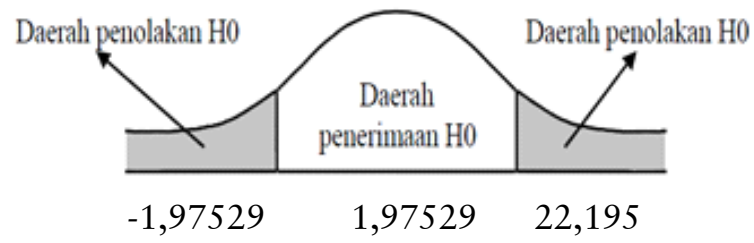

Figure 5 Company Performance Curve Result

\section{Determination Coefficient Test $\left(\mathbf{R}^{2}\right)$}

Table 12 Determination Coefficient Test $\left(\mathrm{R}^{2}\right)$

\begin{tabular}{cccccc}
\hline Model & R & R Square & $\begin{array}{c}\text { Adjusted R } \\
\text { Square }\end{array}$ & $\begin{array}{c}\text { Std. Error of } \\
\text { the Estimate }\end{array}$ & $\begin{array}{c}\text { Durbin- } \\
\text { Watson }\end{array}$ \\
\hline 1 &, $921(\mathrm{a})$ &, 848 &, 845 & 1,1764022 & 1,969 \\
\hline
\end{tabular}

According to Table 12, it is known that the value of Adjusted $R^{2}$ is 0,845 or $84,5 \%$. This indicates the percentage of influence of the independent variables, namely intellectual capital, company growth, and company performance, is $84,5 \%$ towards the dependent variable, which is company value. While the remaining $15.5 \%$ is influenced by other variables that are not discussed in this study.

\section{DISCUSSION}

\section{The Effect of Intellectual Capital towards Company Value}

Intellectual model will leads to innovation and business competition to be more competitive because intellectual capital is a company's source of intangible assets 
which includes the knowledge ability of a company so it will be an added value for the company (Sawarjuwono, 2003). This statement is strengthen by other research by Pramelasari (2010); Ulum (2009); Wijayanti (2012) which stated that intellectual capital can play an important role in increasing company value.

One of the alternatives used to assess company value is to use Tobins'Q. If the value of Tobin's $Q$ is above one, it indicates that investing in assets will generate a return that provides a higher value than the investment expenditure; this can stimulate new investments. If the q-ratio is below one, this indicates that the investment in assets is not attractive. Based on studies by Copeland (2002), and Lindenberg \& Ross (1981) in Darmawati (2004), the studies show how Tobin's $\mathrm{Q}$ can be applied to every company. The study found that several companies were able to maintain a Tobins' $Q$ value of greater than one. The economic theory says that Tobins' $Q$ that is greater than one will attracts new flows of resources and competitions until the Tobins' $Q$ approaches one. It is often difficult to determine whether a high level of Tobin's $Q$ reflects management superiority or the benefits of having a patent.

Based on the hypothesis testing, it shows that intellectual capital has a significant effect on company value within the manufacturing companies tested as measures by Tobins'Q. This shows that the maximum management of intellectual capital is proven to be able to increase company value as measured by Tobins'Q. This finding is in line with the intellectual capital theory which states that the management of all kinds of company resources, including physical capital, human capital, and structural capital will reinforce the formation of added value for the company.

\section{The Effect of Company Growth towards Company Value}

Growth is defined as growth of total assets where past asset growth will represents future profitability and future growth (Kusumajaya, 2011). Company assets show the decisions on the use of funds or investment decision in the past. Assets are defined as a source that have a potential to provide economic benefits to the company in the future. The resources that are believed to be capable of generating cash inflow or reduce cash outflow capacity are referred to as assets (Kallapur \& Trombley, 1999). 
A study conducted by Safrida (2008) proves that company growth has a negative but insignificant effect towards company value. This can happen as the investors have not seen the company's growth as a guidance in investing.

According to the test results, company growth has a negative and insignificant effect towards firm value. The negative sign in this study is on the grounds that the higher the company's growth is, the greater the level of funding needed to finance the company's expansion. The greater needs of funds in the future can also create possibility for the company to hold profits that will be distributed by the company to the investors.

The results of this study are insignificant because investors prefer to see the company's financial performance rather than the company growth as a measure of investment. Thus, any decrease in changes of total assets during the study period does not affect stock price movements among the investors.

\section{The Effect of Company Performance towards Company Value}

Company performance is a form of measurement towards company performance arising from the management decision because it has a relationship between the effectiveness of capital utilization, efficiency, and profitability of performance activities. Company performance achieved by a company reflects the healthiness the company. A healthy company are those who distribute profits to the owners or shareholders. In addition, the company's ability to pay debt on time can indicate that the company is healthy (Fidhayatin \& Dewi, 2012).

From the perspective of the shareholders, ROE is a good measure of company performance. This is because the company's operation aims to create profits that are beneficial for the shareholders. A higher ROE will shows the company's ability to generate large profit for the shareholders, thus increases the company value (Hanafi \& Halim ,1996). This ratio can attract prospective shareholders and management because it can be used as an indicator or a measure for shareholder value creation (Munawir, 2012).

According to the results of the t-test, it asserts that the company performance variable proxied by Return on Equity (ROE) has a significant and positive effect towards company value as measured by Tobins $Q$ with a significance level of $0,000<0,005$. This shows that the higher the ROE value is, the stronger the 
company value will be. Based on the results of this study, it can be concluded that when the level of profit in the company's performance is achieved, thus it will create a positive effect in increasing company value. This is evidenced by the manufacturing companies with an increase in equity (4-11\%) within 2013-2017 period and reported high profits annually, causing an increase of the manufacturing company's attractiveness to the investors as the level of profits will increase. This study is in line with a research by Mahendra et al. (2012) and Afidah (2014) which stated that company performance has a significant positive effect on company value.

\section{Conclusion}

According to the results of the hypothesis testing using the F-testing, it is found that the variables of intellectual capital, company growth, and company performance simultaneously affect company value in manufacturing companies listed on the Indonesian Stock Exchange during the 2013-2017 period. In this study, $80 \%$ of the manufacturing companies shows a good company value from 2013-2017 because they can process and utilize intellectual capital well. A good company performance affects company value, as evidenced by the increase of equity in the manufacturing companies by $4-11 \%$ within the period of 2013 2017 and reporting high company profits every year. This causes an increase in the company's attractiveness to make the manufacturing companies to be more attractive to the investors as the level of profit will be higher, which will increase the shareholder value. This in turn will increase the company's capital.

Company growth is the only variable in this study that shows a negative and insignificant effect. This is due to investors preference to see the company's financial performance instead of company growth as a measurement of investment. Thus, any decrease in changes of total assets during the study period does not affect stock price movements among the investors.

\section{Limitations and Suggestions}

This study cannot be separated by the limitations possessed by the researcher. Including the small number of samples amounting 32 manufacturing companies listed on the Indonesian Stock Exchange (IDX) in the period of 2013- 
2017. The research sample used in this study only includes manufacturing companies, so the results of this study cannot be used as a basis for generalization.

This study uses Asset Growth to project company growth. Asset growth has a weakness, including the high number of negative samples, making the total sample to be little. With the research limitation, it is hoped that future research can increase the number of samples used in the study so the results can be more accurate with a larger number of samples. In addition, future researcher is advised to add the duration of time used, as well as adding other variables that affect company value, such as changes in sales growth, equity growth, and other financial factors.

\section{REFERENCES}

Afidah, U. (2014). Pengaruh Kinerja Keuangan terhadap Nilai Perusahaan dengan Kepemilikan Manajerial sebagai Variabel Moderating (Studi Empiris pada Perusahaan Manufaktur yang Listed di BEI). Jurnal Ilmiah UNEJ, (2010), $1-6$.

Angkoso, N. (2006). Akuntansi Lanjutan. Yogyakarta: Penerbit FE.

Brigham \& Houston. (2010). Dasar-Dasar Manajemen Keuangan Buku 1. Edisi 11. Jakarta: Salemba Empat.

Darmawati, D. (2004). Khomsiyah dan Rahayu. In Corporate Governance and Corporate Performance. National Symposium on Accounting VII. Bali.

Fidhayatin, S.K. \& Dewi, N. (2012). Analisis nilai perusahaan, kinerja perusahaan dan kesempatan bertumbuh perusahaan terhadap Return Saham pada Perusahaan Manufaktur yang Listing di BEI. The Indonesian Accounting Review, 2(2), 203-214.

Hanafi, M. \& Halim, A. (1996). Analisis Keuangan. Yogyakarta: YKPN.

Helfert, E. A. (1997). Teknik Analisis Keuangan. Terjemahan, Herman. Wibowo. Edisi kedelapan. Jakarta: Erlangga.

Izza, I. (2013). Pengaruh Kebijakan Utang, Pertumbuhan Perusahaan, dan Profitabilitas terhadap Nilai Perusahaan (Studi Kasus pada Perusahaan Jii Tahun 2011-2013). Uin Malang. 
Fahmi Achmad Faisal, Suwandi, Nyimas Wardatul Afiqoh / Factors of Company Value: A Study Based on Intellectual Capital, Company Growth, and Company Performance

Kallapur, S. \& Trombley, M. A. (1999). The Association between Investment Opportunity Set Proxies and Realized Broth. Journal of Business and Accounting, 26(3), 505-519. https://doi.org/10.1111/1468-5957.00265.

Kuryanto, B. \& Syafrudin, M. (2012). Pengaruh Modal Intelektual dan Pengungkapannya Terhadap Kinerja Perusahaan. Jurnal Akuntansi dan Keuangan, 14(1), 16-31. https://doi.org/10.18196/JAI-2015.0035.

Kusumajaya, D. K. O. (2011). Pengaruh Struktur Modal dan Pertumbuhan Perusahaan terhadap Profitabilitas dan Nilai Perusahaan pada Perusahaan Manufaktur di Bursa Efek Indonesia. Unpublished Thesis. Universitas Udayana, 1-132.

Mahendra, A., Sri artini, L. G., \& Suarjaya, A. G. (2012). Pengaruh Kinerja Keuangan Terhadap Nilai Perusahaan Manufaktur di Bursa Efek Indonesia. Jurnal Manajemen, Strategi Bisnis dan Kewirausahaan, 6(2), 130-138. https://doi.org/10.1017/CBO9781107415324.004.

Munawir, S. (2012). Analisis Informasi Keuangan. Yogyakarta: Liberty.

Petty, R. \& Guthrie, J. (2000). Journal of Intellectual Capital, 1, 2(155-176), 155-176. https://doi.org/10.1108/14691930210412827.

Pramelasari, Y. M. (2010). Pengaruh Intellectual Capital Terhadap Nilai Pasar dan Kinerja Keuangan Perusahaan. Skripsi. Universitas Diponegoro Semarang. Pulic, A. (1998). Measuring the Performance of Intellectual Potential in Knowledge Economy. The 2nd" World Congress on the Management of Intellectual Capital. https://doi.org/10.1016/j.clinph.2014.05.007.

Safrida, E. (2008). Pengaruh struktur modal dan pertumbuhan perusahaan terhadap nilai perusahaan pada perusahaan manufaktur di Bursa Efek Jakarta. Jurnal Akuntansi Riset UPI, 1(1).

Sawarjuwono, T. (2003). Intellectual Capital: Perlakuan, Pengukuran, dan Pelaporan. Jurnal Akuntansi dan Keuangan, 5(1), 35-57. https://doi.org/10.1024/ 0301-1526.32.1.54.

Sirojudin, G. A. \& Nazaruddin, I. (2014). Pengaruh Modal Intelektual dan Pengungkapannya Terhadap Nilai dan Kinerja Perusahaan. Jurnal Akuntansi dan Investasi, 15(2), 77-89. https://doi.org/10.18196/JAI-2015.0035.

Sukiati, W., Nuryani, N., \& Leviany, T. (2015). Pengaruh Modal Intelektual, Kinerja Keuangan, Investasi pada Riset dan yang Terdaftar di BEI) Munculnya Pernyataan Standar Akuntansi, 7(2), 29-42. 
Susanti, R. (2010). Analisis Faktor-Faktor yang Berpengaruh terhadap Nilai Perusahaan (Studi Kasus pada Perusahaan Go Public yang Listed Tahun 2005-2008), 1-137. https://doi.org/10.1109/ipdps.2012.133.

Taswan. (2003). Analisis Pengaruh Insider Ownership, Kebijakan Utang, dan Dividen terhadap Nilai Perusahaan serta Faktor-Faktor yang Memengaruhinya. Jurnal Ekonomi dan Bisnis.

Ulum, I. (2009). Intellectual Capital Konsep dan Kajian Empiris. Jurnal Inferensi, 7(1), 183-204.

Wijayanti, P. (2012). Pengaruh Intellectual Capital terhadap Harga Saham melalui Kinerja Keuangan pada Perusahaan Perbankan yang Terdaftar di Bursa Efek Indonesia (BEI) pada Tahun 2009-2011. Jurnal Ilmiah Mahasiswa FEB, $1(2)$. 